論文

\title{
原子炉構造材の応力腐食割れに及ぼす環境の影響 $(\mathbf{I})$ 一き裂進展速度に及ぼす流速の影響一
}

\author{
橘 正彦1,*，和田 陽一 1 , 中村 雅人 2 , \\ 布施 元正 $^{2}$ ，永田 暢秋 ${ }^{3}$ ，瀧口 英樹 3
}
Effect of Environment on Stress Corrosion Cracking of Structural Materials in Nuclear Power Plants (I)
-Effect of Flow Rate on Crack Growth Rate-

\author{
Masahiko TACHIBANA ${ }^{1, *}$, Yoichi WADA ${ }^{1}$, Masato NAKAMURA ${ }^{2}$, Motomasa FUSE ${ }^{2}$, \\ Nobuaki NAGATA ${ }^{3}$ and Hideki TAKIGUCHI ${ }^{3}$ \\ ${ }^{1}$ Power \& Industrial Systems R\&D Laboratory, Hitachi, Ltd., 7-2-1 Omika-cho, Hitachi-shi, Ibaraki 319-1221, Japan \\ ${ }^{2}$ Power Systems, Hitachi Works, Hitachi, Ltd., 3-1-1 Saiwai-cho, Hitachi-shi, Ibaraki 317-8511, Japan \\ ${ }^{3}$ The Japan Atomic Power Co., 1-1 Kanda Mitoshiro-cho, Chiyoda-ku, Tokyo 101-0053, Japan
}

(Received June 27, 2006 and accepted in revised form February 7, 2007)**

\begin{abstract}
We studied the effect of the flow rate of reactor water on crack growth rates (CGRs) in a boiling water reactor (BWR) coolant system using 1/4TCT specimens made of sensitized 304 stainless steel (SUS304). Specimen electrochemical corrosion potentials (ECPs) in each oxidant concentration increased with increasing of water flow. This was caused by the increase of the mass transfer amount from bulk water to the specimen surface through a diffusion layer determined by the water flow. A relative CGR was defined as the ratio of the CGR under a given set of conditions to that under simulated normal water chemistry (NWC) at a low flow rate. The relative CGRs at high flow rates were higher than those at low flow rates under NWC. However, when the concentration of oxidants was below $10 \mathrm{ppb}$ and the specimen ECP was below $-0.15 \mathrm{~V}$ vs. Standard Hydrogen Electrode, the relative CGRs at high flow rates became as low as those at low flow rates. The mass flux of the oxidant was one dominant parameter, which controlled the CGRs at high flow rates. Although the flow rates in a BWR vessel and piping are very high, the CGRs should decrease when the oxidant concentration is adequately reduced by applying hydrogen water chemistry.
\end{abstract}

\footnotetext{
KEYWORDS: boiling water reactor, stainless steel, stress corrosion cracking, crack growth rate, flow rate, hydrogen water chemistry, electrochemical corrosion potential, hydrogen peroxide, corrosion current, mass transfer
}

\section{I. 緒 言}

沸騰水型原子炉 (Boiling Water Reactor : BWR)では, 粒界型応力腐食割れ (Intergranular Stress Corrosion Cracking : IGSCC) 抑制のために, 多数のプラントで水素 注入 (Hydrogen Water Chemistry : HWC) を適用してい る1)。IGSCC の発生, および進展を水素注入技術により

\footnotetext{
1 秼日立製作所 電力・電機開発研究所

2 侏日立製作所 原子力事業部

3 日本原子力発電秼

* Corresponding author, E-mail: masahiko.tachibana.kh@hitachi. com

**本論文は,「研究論文」として受理・審査された。
}

(C)Atomic Energy Society of Japan

緩和する場合，その効果の指標として，原子炉一次冷却 水(炉水) 中の酸素, 過酸化水素などの酸化剂濃度や, 構 造材料の腐食電位 (Electrochemical Corrosion Potential: $\mathrm{ECP})$ が用いられる。ECPは, 高温水中でその場測定がで きることから, 近年 IGSCC の環境指標として広く用いら れている。

鋭敏化 SUS304 鋼においては, ECP が-0.23 V versus Standard Hydrogen Electrode (vs. SHE) 以下で IGSCC の 発生が抑制されることが報告されている2)。また, ECP と き裂進展速度 (Crack Growth Rate : CGR)にも相関があり, CGR は ECPに対して S 字状の関数として表現され， $\mathrm{ECP}$ の低下とともに CGR もまた低減する3)。そのため, 水素注入の適用によって $\mathrm{ECP}$ を低下させることで, 
IGSCC の対策が図られてきた。

しかし, 高水素濃度の水素注入ではタービン系への ${ }^{16} \mathrm{~N}$ の移行が増え，それにより主蒸気系線量率が上昇4するた めに，国内 BWR で水素注入を適用する場合，その多くで は給水水素濃度を $0.4 \sim 0.6 \mathrm{ppm}$ とする運用が行われてい る。

水素注入時は, 炉水の放射線分解によって生成する過酸 化水素が主として ECPを決定する5)。過酸化水素は, BWRの運転温度では熱分解するため，これまで，実験室 系での過酸化水素を用いた試験は難しかった。そのため, $\mathrm{ECP}$ と CGR の相関を調べる材料試験では，大部分は酸化 剂として酸素を添加して BWR 炉内条件を模擬していた。 しかし近年，過酸化水素環境での知見 ${ }^{5 \sim 7)}$ が増え，過酸化 水素環境では酸素環境と腐食挙動が異なることが明らかと なってきた。

例えば Wada $ら^{6)}$ は, 数 $10 \mathrm{ppb}$ 程度の低濃度過酸化水 素が存在する場合の, SUS304 鋼の ECP，および CGR を 原子炬内模擬水質中で実測した。その結果, CGRの ECP 依存性は，低濃度で高 ECP となる過酸化水素環境におい ては，同じ ECPであっても，過酸化水素環境の CGR の 方が酸素環境よりも遅いとしている。その他にも，酸素環 境と過酸化水素環境とでは，ステンレス鋼表面に生ずる酸 化皮膜の形態，および電気的性状が異なることなどが報告 されている8,9)。

以上述べたように，近年，過酸化水素環境に打知見 が増えつつある。過酸化水素環境に抢ける CGR 挙動につ いては，さらに以下(1)〜(3)に示す影響を検討し，酸素環境 と比較することで，実機炉内 CGR 挙動の明確化につなが
るものと考える。

（1）流速の影響

BWR 炉内の流動条件を Table 1 に示す。炉水の流速が $\mathrm{m} \cdot \mathrm{s}^{-1}$ オーダーであるため10)，ECP が流速によって上昇 する作用11 14) が影響して CGR が上昇するのか，または フラッシング15)によって CGR が低下するのかを明確にす る必要がある。

(2) 放射線の影響

また，実機炉内ではき裂内部で過酸化水素が生成するた め, ECP と CGRの相関は実験室系とは異なる可能性があ る。しかし $\gamma$ 線照射による CGR への影響を過酸化水素の 観点から検討した知見は少ない。

（3）鋭敏化 SUS304 鋼以外の構造材料への影響 鋭敏化 SUS304 鋼以外にも，BWR 炉内では Alloy182 合金が炉内構造材料の溶接金属として用いられているため,

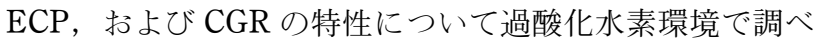
る必要がある。

本研究では, 過酸化水素環境での BWR 炉内の環境が CGR に及ぼす影響として，まず(1)に示す流れの影響につ いて調べた。過酸化水素濃度を制御して，1/4TCT 試験 片のノッチ内に通水して流速を与えたときの CGR の変化 について検討した。

これまで，IGSCC 発生挙動に及ぼす流速の影響につい ては, $553 \mathrm{~K}$ に打いて $0.01 \mathrm{M} の \mathrm{Na}_{2} \mathrm{SO}_{4}$ 中で $\mathrm{SUS} 304$ 鋼 の低歪速度試験 (Slow Strain Rate Test : SSRT)を行った 結果, IGSCC 発生臨界電位には影響しないとの報告や16), $523 \mathrm{~K}$ に打けるSSRT試験の結果，流れを与えると SUS304鋼の破断時間が増大する結果 ${ }^{17,18)}$ が報告されてい

Table 1 Flow conditions and calculated mass transfer coefficients in BWR coolant circuit

\begin{tabular}{|c|c|c|c|c|c|c|c|c|c|}
\hline$\#$ & Region & $\begin{array}{l}\text { Flow rate } \\
/ \mathrm{cm} \cdot \mathrm{s}^{-1}\end{array}$ & $\begin{array}{l}\text { Diameter } \\
/ \mathrm{cm}\end{array}$ & $\begin{array}{c}\text { Temperature } \\
/ \mathrm{K}\end{array}$ & $\begin{array}{c}\text { Kinematic } \\
\text { viscosity } \\
\text { coefficient } \\
/ \mathrm{cm}^{2} \cdot \mathrm{s}^{-1}\end{array}$ & $\begin{array}{l}\text { Diffusion } \\
\text { coefficient }{ }^{28)} \\
/ \mathrm{cm} \cdot \mathrm{s}^{-1}\end{array}$ & $\begin{array}{l}R e \\
/ 10^{6}\end{array}$ & $S c$ & $\begin{array}{c}\kappa \\
/ \mathrm{cm} \cdot \mathrm{s}^{-1}\end{array}$ \\
\hline 1 & Lower plenum & 210 & 18 & \multirow{10}{*}{549} & \multirow{10}{*}{$1.32 \times 10^{-3}$} & \multirow{10}{*}{$3.28 \times 10^{-4}$} & 2.77 & \multirow{10}{*}{4.01} & 0.110 \\
\hline 2 & Core bypass & 25 & 8 & & & & 0.146 & & 0.024 \\
\hline 3 & Mixing plenum & 50 & 97 & & & & 3.74 & & 0.025 \\
\hline 4 & Downcomer & 150 & 77 & & & & 8.71 & & 0.063 \\
\hline 5 & Downcomer (Bottom) & 110 & 120 & & & & 10.1 & & 0.045 \\
\hline 6 & PLR (Primary loop recirculation) & 940 & 62 & & & & 44.2 & & 0.286 \\
\hline 7 & Jet pump (riser) & 950 & 28 & & & & 19.9 & & 0.338 \\
\hline 8 & Jet pump (mixer) & 2,600 & 17 & & & & 33.9 & & 0.822 \\
\hline 9 & Jet pump (diffuser) & 420 & 43 & & & & 13.6 & & 0.160 \\
\hline 10 & $\begin{array}{l}\text { RPV (Reactor pressure vessel) } \\
\text { (Bottom) }\end{array}$ & 190 & 20 & & & & 2.93 & & 0.101 \\
\hline 11 & Low flow cell (This work) & 0.4 & 3.3 & \multirow{2}{*}{561} & \multirow{2}{*}{$1.29 \times 10^{-3}$} & \multirow{2}{*}{$3.51 \times 10^{-4}$} & - & \multirow{2}{*}{3.89} & 0.007 \\
\hline 12 & High flow cell (This work) & 20 & 0.2 & & & & 0.003 & & 0.042 \\
\hline
\end{tabular}

$R e$ : Reynolds Number, $S c$ : Schmidt Number, $\kappa$ : turbulent mass transfer rate 
る。これは，いったんき裂が発生すると，流れがき裂内に 流動を起こし，き裂内の水質が変化するためと推定されて いる。これら SSRT 試験の知見によれば，IGSCCの発生 挙動は, 流速の上昇によって悪化しないことになる。

IGSCC 進展挙動については，従来行われてきたき裂進 展試験では，試験片が置かれる試験槽内の流速は遅く，準 静止水とみなせる状態での実施がほとんどであった。その ため，実験の流速と実機 BWR 炉内の流速とは数桁の差異 が生じる。

Kwon ら ${ }^{19)}$ や Andresen ${ }^{15)}$ は，IGSCC 進展挙動に及ぼす 流速の影響を，コンパクトテンション(Compact Tension : CT)試験片を用いたき裂進展速度測定により調べた結果， 流速上昇により ECP は上昇するにも関わらず，き裂内に 濃縮した不純物イオンを流れが「フラッシング」により浄 化するため，高流速条件では CGR が低下することを報告 している。流速増大により ECP が上昇するにも関わらず CGRが緩和されることは，従来の，ECP 低下により CGR が低減される知見と矛盾する。したがって，実機の ような高流速下に打ける水素注入の効果の評価に，従来の ECP と CGR の相関を用いることが有効であるかどうかは 不明瞭である。しかし，これまでに低濃度過酸化水素環境 で，CGR に及ぼす流れの影響を検討した例はない。

過酸化水素環境では, 酸素環境より低濃度で高 $\mathrm{ECP}$ と なることから ${ }^{6)}$ ，流速変化によるわずかな供給量変化によ り大きな ECP 変化が予想され流れの影響をより明確にで きると考える。

\section{II. 実 験 方 法}

\section{1. 試験片}

CGR 測定に供する CT 試験片の材料は，Table 2 に示 す組成の高炭素濃度 $([\mathrm{C}]=0.06 \%)$ ) SUS304 鋼を用い た。熱処理は，溶体化処理 $(1,323 \mathrm{~K} \times 30 \mathrm{~min}$ ，水冷）した 後に, 溶接後の低温鋭敏化を考慮した熱処理 $(1,023 \mathrm{~K} \times$ $100 \mathrm{~min}$, 水冷 $; 773 \mathrm{~K} \times 24 \mathrm{~h}$, 空冷) 20 ) 行った。本材料 を, JIS G0580に基づいて電気化学的再活性化率を測定 した結果は $33.3 \%$ あ゙あり，強鋭敏化していることを確認し た。鋭敏化の後, Fig. 1 に示す形状に切り出して $1 / 4$ TCT 試験片6,7) を作成し，室温大気中で JSME (The Japan Society of Mechanical Engineers) S 001-1992 に規定され る限界荷重を超えない最大荷重で疲労予き裂を導入した。 初期規格化疲労予き裂長さ $\left(a_{0} / W\right)$ は，JSME S 001-1992 の規定值 $\left(0.5 W \leqq a_{0} \leqq 0.75 W\right)$ に基づき， $a_{0} / W=0.5$ まで 導入した。

Table 2 Chemical composition of test material (type 304 stainless steel)

\begin{tabular}{ccccccccc}
\hline Composition & $\mathrm{C}$ & $\mathrm{Si}$ & $\mathrm{Mn}$ & $\mathrm{P}$ & $\mathrm{S}$ & $\mathrm{Ni}$ & $\mathrm{Cr}$ & $\mathrm{Fe}$ \\
\hline wt $\%$ & 0.06 & 0.42 & 0.83 & 0.028 & 0.005 & 8.41 & 18.32 & $\mathrm{Bal}$. \\
\hline
\end{tabular}

疲労予き裂の導入後, 外面を\#600までエメリー研磨 し, アセトン, 超純水中で脱脂, 洗浄した後に試験に供し た。低流速用，高流速用に各 1 個の試験片を作成した。

CGRの測定は，電位差法 (Potential Drop Method : PDM ${ }^{7)}$ によって，き裂進展長をオンラインで連続モニタ リングした。

疲労予き裂の導入により生ずる，き裂先端近傍での平面 ひずみによる塑性域寸法 $R_{\mathrm{p}}$ を，JSME S 001-1992 に従っ て評価した結果，約 $110 \mu \mathrm{m}$ と得られた。そのため，試験 温度に到達した後に $150 \sim 190 \mu \mathrm{m}$ の SCC 予き裂を導入し た。これにより，き裂の先端位置が塑性域を通過した後に CGR を測定することで，塑性域の影響を除いた。

1/4 インチ厚の小寸法試験片を用いた理由は，1)試験片 表面積の微小化による過酸化水素の表面接触分解5)の抑制, $2)$ 試験水流路面積を減少させ, 流速を増大し, 滞在時間 を短くすることにより過酸化水素の熱分解を抑制するた め5)である。本研究では, 水質の制御性を優先した結果, 小規模降伏条件を満たさないため, CGRの絶対值につい ては議論しない。

\section{2. 試験水質}

水質条件は，実機条件に近づけるために，水質解析コー ド (SIMulation For Optimum Net Yield in chemical engineering plants:SIMFONY)21)を用いて，BWR5 におけ る水素注入技術適用時の炉底部水質, および ECP を解析 した結果に基づいて設定した。種々の水素注入量に対応す る条件として, Table 3 に示すように, 高 $\mathrm{ECP}($ 約 $0 \sim 50$ $\mathrm{mV}$ vs. SHE), 中 $\mathrm{ECP}$ (約 $-100 \mathrm{mV}$ vs. SHE), 低 ECP (約 $-250 \mathrm{mV}$ vs. SHE) の水素注入条件, 抢よび, NWC 条件(約 $200 \mathrm{mV}$ vs. SHE)の計 4 条件とした。試験片の $\mathrm{ECP}$ が目標 ECP となるよう, 水素, 酸素, および過酸 化水素の添加濃度を調整した。各水質で線流速は，準静止

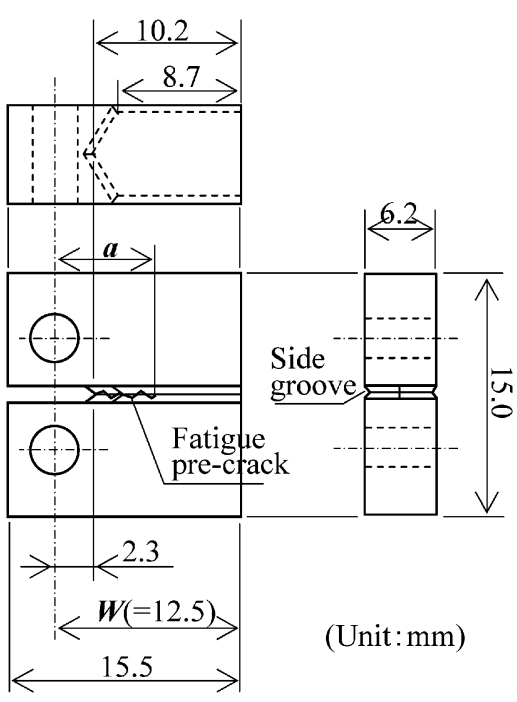

Fig. 1 Schematics of CT specimen

日本原子力学会和文論文誌, Vol. 6, No. 2 (2007) 
水とみなせる $4 \mathrm{~mm} \cdot \mathrm{s}^{-1}$ (低流速) と, 乱流物質移動係数の 值を BWR 炉内の条件に合わせた $20 \mathrm{~cm} \cdot \mathrm{s}^{-1}$ (高流速)の 2 種の条件で ECP，抢よび CGR を測定した。

高濃度の過酸化水素雾囲気で形成された酸化皮膜は, 酸 化側から還元側に水質を変化させたときにヒステリシス特 性をもち，還元雲囲気でも高い ECP を保持する可能性が ある5)。したがって酸化䨌囲気から還元雾囲気に切り替え る場合には，酸化皮膜が十分に還元されるまで長時間保持 し，直前の水質の影響を除く必要がある。しかし， $1 / 4$ TCT 試験片を使用する場合には，長時間の保持によりリ ガメント幅が短くなる場合がある。そこで実験水質は，ヒ ステリシスの影響を受けないよう, 還元雲囲気から高酸化 雾囲気の順で切り替えた。ここで, リガメント幅とは, Fig. 1 に示す $W-a$ で定義されるき裂進展部の残留長さで ある。

Table 3 Experimental conditions and results

\begin{tabular}{|c|c|c|c|c|c|}
\hline \multirow{2}{*}{$\begin{array}{c}\text { Target } \\
\text { environment }\end{array}$} & \multirow{2}{*}{$\begin{array}{l}\text { Flow } \\
\text { rate } \\
/ \mathrm{cm} \cdot \mathrm{s}^{-1}\end{array}$} & \multicolumn{2}{|c|}{$\begin{array}{c}\text { Concentration } \\
/ \mathrm{ppb}\end{array}$} & \multirow{2}{*}{$\begin{array}{c}\text { ECP } \\
\text { (measured) } \\
/ \mathrm{mV} \text { vs. SHE }\end{array}$} & \multirow{2}{*}{$\begin{array}{c}\text { Relative } \\
\text { CGR/- }\end{array}$} \\
\hline & & $\mathrm{H}_{2} \mathrm{O}_{2} \quad \mathrm{O}_{2}$ & $\mathrm{H}_{2}$ & & \\
\hline NWC & \multirow{4}{*}{0.4} & 207100 & 10 & 180 & 1.0 \\
\hline High ECP & & 20 & & 54 & 0.13 \\
\hline Middle ECP & & 11 & 50 & -100 & 0.11 \\
\hline Low ECP & & 1 & & -291 & 0.21 \\
\hline NWC & \multirow{4}{*}{20} & 219100 & 10 & 138 & 6.0 \\
\hline High ECP & & 24 & & -120 & 2.0 \\
\hline Middle ECP & & $11<1$ & 50 & -140 & 1.0 \\
\hline Low ECP & & 2 & & -156 & 0.14 \\
\hline
\end{tabular}

\section{3. 試験装置}

試験に用いた高温高圧水ループの概要を Fig. 2 に示 す。試験部の酸素, 水素濃度は, 酸素濃度調整タンク, 水 素濃度調整タンクでそれぞれ濃度を調整し, 等流量 $(5$ $\left.\mathrm{dm}^{3} \cdot \mathrm{h}^{-1}\right)$ で混合する方法で制御した。総給水流量は 10 $\mathrm{dm}^{3} \cdot \mathrm{h}^{-1}$ で試験を行った。両タンクともに, イオン交換 樹脂に連続通水して不純物イオンを除去し, 試験中の給水 導電率を $1 \times 10^{-5} \mathrm{~S} \cdot \mathrm{m}^{-1}$ 以下に保った。試験水温度は, $561 \pm 1 \mathrm{~K}$ に制御した。試験圧力は，沸騰を防ぐため 8.3 MPa とした。過酸化水素注入系の配管内面, およびオー トクレーブ内金属面, 荷重負荷冶具など試験片以外の金属 部材を四弗化エチレン (Polytetrafluoroethylene : PTFE) で被覆して, 過酸化水素の接触分解を防いだ5)。各水質条 件において, 試験片近くからオートクレーブ内の試験水を 採取し, 試験片位置での過酸化水素濃度を確認した ${ }^{5)}$ 。

流速は, CT 試験片周りの流路断面積の異なる 2 種の測 定セルを用いて調整した。Figure 3 に低流速試験時の試 験部概観を示す。荷重負荷治具に装荷した CT 試験片の周 りを, 内径 $\phi 33 \mathrm{~mm}$ の円筒形の PTFE 製測定セルで覆 い，測定セルに高温水導入管を直接接続することにより， セル内を全循環流量が流れる構造とした。このとき, セル 内を上昇する線流速は約 $4 \mathrm{~mm} \cdot \mathrm{s}^{-1}$ である。ノッチ内は, 流れが遅いため, 滞留などの影響もあり, 緩やかに横方向 に流れていると推定する。Uchida $5^{5)}$ と同手法で CT 試 験片位置での過酸化水素濃度 $C_{\mathrm{CT}}$ を求め, $\mathrm{CT}$ 試験片位置 での過酸化水素残存率 $\eta_{\mathrm{CT}}$ を評価したところ ${ }^{5)}, 80 \%$ と得 られた。

$$
\eta_{\mathrm{CT}}=C_{\mathrm{CT}} \cdot C_{\text {in }}^{-1}
$$

ここで， $C_{\text {in }}$ は過酸化水素注入点での過酸化水素濃度を 示す。熱分解定数は, $0.014 \mathrm{~s}^{-1}$, ステンレス鋼の表面接

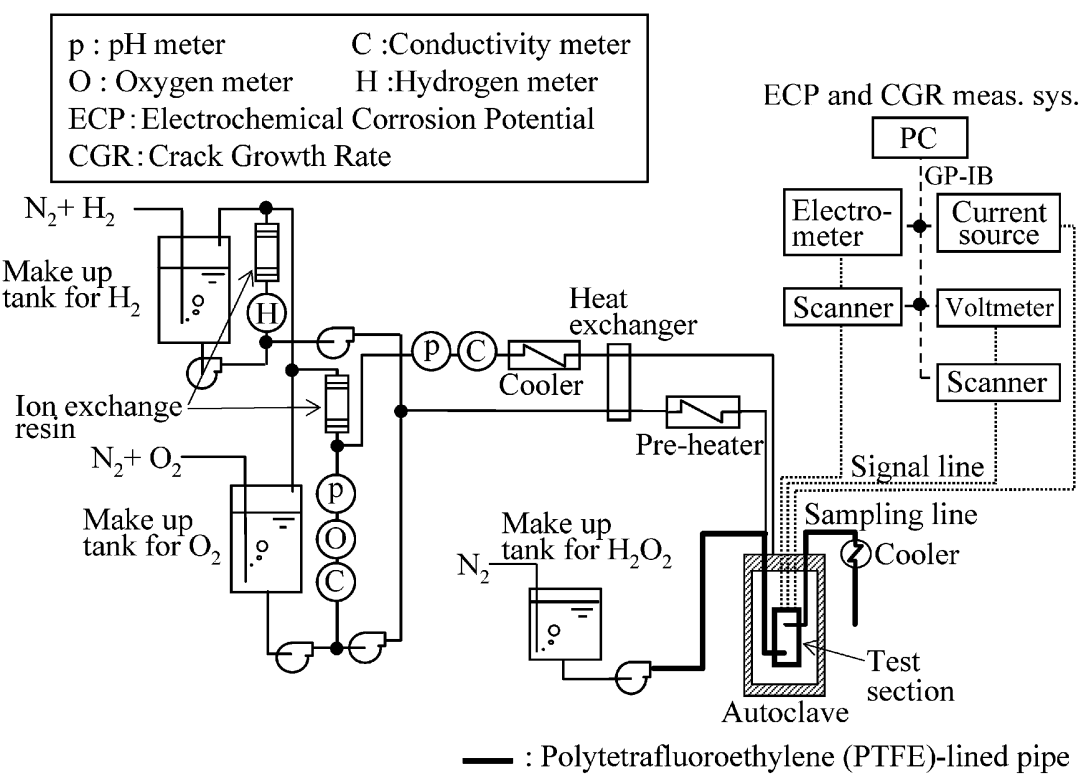

Fig. 2 Schematic of BWR water chemistry control loop 


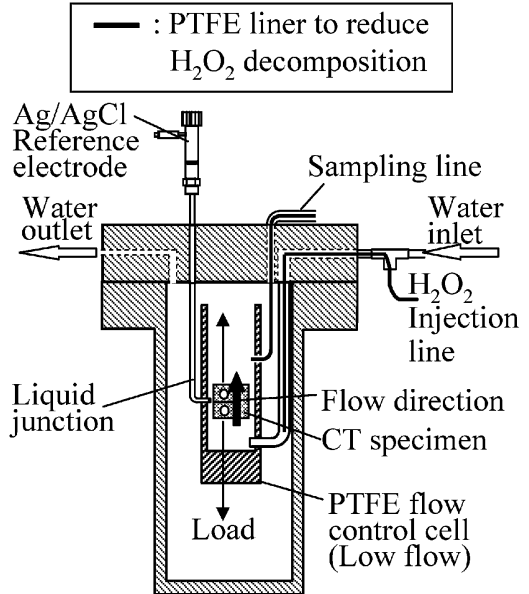

Fig. 3 Cutaway view of autoclave and measurement cell for low flow rate

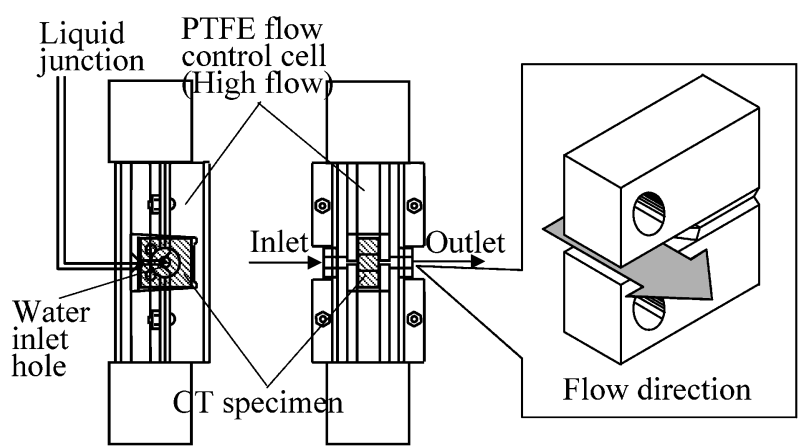

Fig. 4 Cutaway view of measurement cell for high flow rate

触分解定数は $2.3 \times 10^{-4} \mathrm{~m} \cdot \mathrm{s}^{-1}$, PTFE の表面接触分解定 数は $2.3 \times 10^{-6} \mathrm{~m} \cdot \mathrm{s}^{-1}$ を使用した ${ }^{5)}$ 。

一方, 高流速用測定セルは箱型とし, CT 試験片の全面 を $1 \mathrm{~mm}$ の間隙を設けて覆う形状とした。Figure 4 に高 流速用セルの概観を示す。CT 試験片のノッチ部側面に位 置する箇所に高温水導入孔を開け，この孔に高温水導入管 を直接接続することで, 全循環流量が CT 試験片のノッチ 部を流れる構造とした。これにより $20 \mathrm{~cm} \cdot \mathrm{s}^{-1}$ の流速を 形成させた。そのため, 高流速用測定セルを設置した場合 は, Fig. 4 にあわせて示したようにき裂に水平方向の流机 となる。これによって, 物質移動係数が実機炉内のダウン カマ領域と同等の值となるようにした。

試験水々接触する試験片以外の金属部材は PTFE で覆 ったため, 低流速, 高流速ともに熱分解が主となり，よっ て過酸化水素残存率は時間の関数となる。高流速時は, 過 酸化水素注入点から CT 試験片位置まで短時間で到達する ため, CT 試験片位置での過酸化水素残存率が $97 \%$ に向上 した。低流速, 高流速ともに過酸化水素の残存率を考慮し, $\mathrm{CT}$ 試験片設置部の濃度が目標濃度となるよう, 過酸化水 素の注入濃度を調節した。

ECP は，エレクトロメータ (Keithley, 6512)，スキャナ
(Keithley, 7001)，スキャナカード (Keithley, 7058)，打 よび $\mathrm{Ag} / \mathrm{AgCl}$ 型外部照合電極 (東伸工業侏)を用いて測定 した。き裂進展部に近い位置の ECP を評価するために, 低流速条件では CT 試験片ノッチ内に外部参照電極の液絡 管を約 $5 \mathrm{~mm}$ 挿入した。高流速条件では CT 試験片のノッ チ内を試験水流路とするため, ノッチ内に外部参照電極の 液絡管を深く指入できない。そのため, 液絡管をノッチ内 に約 $1 \mathrm{~mm}$ 挿入した状態で固定して測定した。そのため, 低流速条件とは液絡管の挿入深さが約 $4 \mathrm{~mm}$ 異なる。高流 速条件ではノッチ内を強制流通させたため, ノッチ内面全 体がカソード面を代表する ECP とみなせる。低流速条件 では, ノッチ内の ECP がバルク水中に設置した板状電極 と同じ ECP 挙動を示す6)ことがわかっているため, カ ソード面を代表する ECP と久なせる。したがって，挿入 深さに相違があるが，双方カソード面を代表する ECP と して直接比較が可能な值である。

CGR は， 4 線式の交番直流電位差法 (Reversing Direct Current-Potential Drop Method：RDC-PDM)を用いて測 定した ${ }^{7)}$ 。測定終了後に試験片を強制破断し, 走查型電子 顕微鏡 (Scanning Electron Microscope : SEM)を用いて破 面観察を行い, 破面面積と試験片幅から平均き裂長さを算 出し, RDC-PDM で測定したき裂進展量を補正して CGR を求めた。

\section{4. 荷重条件}

CT 試験片に負荷する目標初期応力拡大係数 ( $K$ 值) は $25 \mathrm{MPa} \cdot \mathrm{m}^{0.5}$ とした。1/4 TCT 試験片のように試験片幅 が小さいCT 試験片を用いる場合, JSME S 001-1992 記 載の寸法効果を考慮する必要がある。本来, き裂進展破面 は平面ひずみ状態であり, 引張型の破壊を生じる。しかし $\mathrm{CT}$ 試験片の側面近傍では, 平面応力状態となるため, 引 張型よりもむしろせん断型に近い破壊となる。CT 試験片 の幅が小さい場合, 試験片の幅が大きい場合よりも全破面 面積に抢ける塑性変形領域の面積の占める割合が多くな る。これを防ぐ目的で, 本研究の CT 試験片には, 角度 $90^{\circ}$, 深さ $0.538 \mathrm{~mm}$ の $\mathrm{V}$ 字型側溝 (Fig. 1) を両側面に設 け，極力平面ひずみ場に拘束されるようにした。

CT 試験片の寸法が CGR に及ぼす影響については, 現 在までに以下の知見が得られている。

Sato ら ${ }^{22)}$ は，熱間圧延 SUS304 鋼で種々の寸法のCT 試験片を作成し，BWR 環境でのCGR の差異を調べた。 その結果は, BWR 条件で厚さ $6 \mathrm{~mm}$ の RCT 試験片に小 規模降伏条件を満たさない $K$ 值を付与したとき, $1 \mathrm{TCT}$ 試験片よりもCGR が遅い結果を得ている。

一方，小寸法の RCT 試験片を用い，561 Kに打ける CGR を測定した報告では, 同じ降伏強度の $1 \mathrm{TCT}$ 試験片 で測定した CGR よりも 1 桁以上速い結果となることが報 告されている23)。

オーステナイト鋼で CT 試験片を作製した場合，付与す 
る応力拡大係数は, ASTM E-399 で規定される下式を満 たす必要がある。

$$
B_{\mathrm{eff}}, a \geq 2.5\left(\frac{K_{\mathrm{I}}}{\sigma_{\mathrm{ys}}}\right)^{2}
$$

ここで, $B_{\mathrm{eff}}$ は $\sqrt{B+B_{\mathrm{SG}}}$ で求められる有効試験片厚さ, $B$ は試験片の厚さ， $B_{\mathrm{SG}}$ は側溝部の試験片厚さ, $a$ はき裂長 さ (Fig. 1 参照), $K_{\mathrm{I}}$ は応力拡大係数, $\sigma_{\mathrm{ys}}$ は降伏応力を示 す。

本研究で用いた $1 / 4 \mathrm{TCT}$ 試験片の有効性を以下に検討 した。（2 )式に拈いて，SUS304のように，加工硬化する 延性材料であるオーステナイトステンレス鋼では， $\sigma_{\mathrm{ys}}$ に 替えて,（3)式で求まる有効降伏強度 $\sigma_{\mathrm{fs}}$ を用いて評価す $ろ^{23)}$ 。

$$
\sigma_{\mathrm{fs}}=\frac{\left(\sigma_{\mathrm{ys}}+\sigma_{\mathrm{B}}\right)}{2}
$$

ここで， $\sigma_{\mathrm{B}}$ は引張強度である。

(3) 式の $\sigma_{\mathrm{ys}}$ に $573 \mathrm{~K}$ における鋭敏化 SUS304の0.2\% 耐力を代入し， $\sigma_{\mathrm{B}}$ に同温度の引張強度を代入して求めた $\sigma_{\mathrm{fs}}$ は, $288 \mathrm{MPa}^{24)}$ である。この值を用いると, (2)式か ら, $1 / 4 \mathrm{TCT}$ 試験片の許容最大応力拡大係数は $13.7 \mathrm{MPa}$ $\cdot \mathrm{m}^{0.5}$ となり, 本研究で付与した目標初期応力拡大係数 25 $\mathrm{MPa} \cdot \mathrm{m}^{0.5}$ は最大許容応力拡大係数を超過することにな る。そのため, $1 \mathrm{TCT}$ 試験片のような大寸法の試験片を 用いて最大許容応力拡大係数の範囲内で測定された CGR と異なり，CGR 值の有効性が保証されない。しかし，上 記の許容值を満たす $K$ 值では， $1 / 4 \mathrm{TCT}$ 試験片でき裂が 進展しなかったため, 安定にき裂を進展させるために目標 初期応力拡大係数を $25 \mathrm{MPa} \cdot \mathrm{m}^{0.5}$ とした。

1/4 TCT 試験片を使用すると, 上述のように小規模降 伏条件を満たさず，力学的な有効性が得られないが，本研 究で小寸法の試験片を用いたのは，以下に述べるように過 酸化水素環境の制御性を確保し，水質の影響を抽出して評 価するためである。

本研究では，過酸化水素を添加することで BWR の炉水 環境を模擬する。過酸化水素は高温で熱抢よび金属表面々 の接触で速やかに酸素々水に分解する。そのため, PTFE セルで高温部の流路を形成して接触分解を抑制するととも に，過酸化水素混合点から CT 試験片までの滞在時間を短 くし熱分解を抑制した ${ }^{5 \sim 7)}$ 。そのため, 試験片周りの流路 面積も最小とする必要があるが，大寸法の試験片では流速 が低下し，CT 試験片位置に至るまでの過酸化水素分解量 が多くなる。これまでの研究から，1/4TCT 試験片であ っても, 水質変化に追従して CGR 值が変化することがわ かっているため 6,7$)$, 過酸化水素濃度の制御性を優先して 1/4 TCT 試験片を用いた。このため本研究では，き裂進 展速度の絶対值を求めることよりも, 環境の変化に対応す るき裂進展速度の変化を重視した。ここで，小寸法 CTを 用いた場合，全 ECP 域で均等に CGR が速くなるものと 仮定し，水質変化時の CGR の相対変化量の比較は有効と
考えた。そこで本研究では, NWC, 低流速での CGR 值 を基準とした相対 CGR を用いて環境効果を調べた。

CT 試験片に付与する荷重は定荷重としたが，次に示す 検討から，応力比 $0.7 の$ 周期的除荷を実施した。

Weinstein ${ }^{25)}$ は, 定変位を付与した 2 重片持梁型試験片 を使用した CGR 測定結果から，2,500 h までは非常に低 速度の CGR であったと報告している。また, Andresen ${ }^{26)}$ の報告では, 定荷重や特に定変位型の試験片を用いた CGR 測定では, 脱気純水中のような, 腐食性の弱い環境 中での CGR にばらつきが生じる。このような場合, 定期 的に除荷負荷を行うことで, 精度と再現性の向上が期待で きるとしている。その中で, $100 \mathrm{~s}$, あるいは $10,000 \mathrm{~s}$ 保 持後に応力比 $\mathrm{R}=0.7,0.01 \mathrm{~Hz}$ の条件で周期的に除荷する ことで, CGR 測定の精度と再現性が向上することが述べ られている。

そのため本研究では, 低酸化種濃度環境でのき裂を安定 に進展させることで, 水質の差異のみを比較することを目 的として，10,000 s 保持ごとに設定荷重の $70 \%(\mathrm{R}=0.7$, $0.003 \mathrm{~Hz}$ ) とする除荷負荷を実施した。

Andresen ら ${ }^{26)}$ は, 上記の定期的除荷によって, 測定さ れるCGR が，除荷のない場合に比して約 2 倍程度に大き くなるとしている。本研究では, 前述したように相対 CGR を用いるため, 除荷による CGR の増加率は打ち消 されるものと考える。

小寸法の CT 試験片では, リガメント幅 $W-a$ が小さい ために，き裂の進展に伴う $K$ 值の変化が大きく，その結 果き裂進展に伴いCGR が増大する。これを避けるため に, 試験中は分解能 $0.01 \mathrm{~mm} の$ 変位計を監視し, 試験片 の開口がないことを監視した。これにより塑性変形が生じ て試験中にCGR が増大することはなかったと判断した。 同様に, 試験中の $K$ 值の急激な変化を防ぐため, き裂進 展量が $500 \mu \mathrm{m}$ 以下の範囲でのみ試験を行った。そのため, 1 水質条件当たりの保持時間は，約 $48 \sim 72 \mathrm{~h}$ とした。試 験後の破面観察から求めた初期 $K$ 值, および終了時 $K$ 值 の範囲は，低流速用試験片で $28.0 \sim 28.2 \mathrm{MPa} \cdot \mathrm{m}^{0.5}$, 高流 速用試験片で $29.6 \sim 32.3 \mathrm{MPa} \cdot \mathrm{m}^{0.5}$ であった。

\section{III. 実 験 結 果}

\section{ECP 測定結果}

Table 3 に，水質の試験マトリックス，および ECP と CGR の測定結果をあわせて示す。ECP, および相対 CGR は, 水質の変化に追従し, 高流速および低流速のいずれで も, 水素注入時水質とすると, 酸化種 (酸素, 過酸化水素) 濃度の減少とともに低下した。

Figure 5 に, CT 試験片の ECP を実効酸素濃度 $\left[\mathrm{O}_{2}\right]_{\mathrm{eff}}$ $\left(=\left[\mathrm{O}_{2}\right]+1 / 2\left[\mathrm{H}_{2} \mathrm{O}_{2}\right]\right)$ で整理した結果を文献值 $\left.{ }^{5,6}\right)$ ととも に示す。本試験における酸化種は, ほぼ過酸化水素のみと みなせるが, 対照条件の通常水質では過酸化水素と酸素が 共存することから，2 成分を同時に示すために横軸を実効 
酸素濃度で表した。文献值はいずれもSUS304 板状試験 片で得られた值である。

ECP は，低流速，高流速ともに実効酸素濃度の増加と ともに上昇した。本研究の結果は, 従来の過酸化水素環境 での結果5,6) と同様に, 低流速, 高流速ともに, 低濃度側 で酸素環境よりも高い ECP を指示した。低流速での ECP は, 1 から $10 \mathrm{ppb}$ の領域で実効酸素濃度増加に伴って大 きく上昇し，10から $100 \mathrm{ppb}$ の領域では濃度変化に伴う 変化量が比較的小さかった。一方, 高流速での ECP は, $10 \mathrm{ppb}$ 以下で実効酸素濃度増加に伴う $\mathrm{ECP}$ 变化が小さく, $10 \mathrm{ppb}$ 以上で濃度変化に伴う変化量が比較的大きい傾向 を示した。

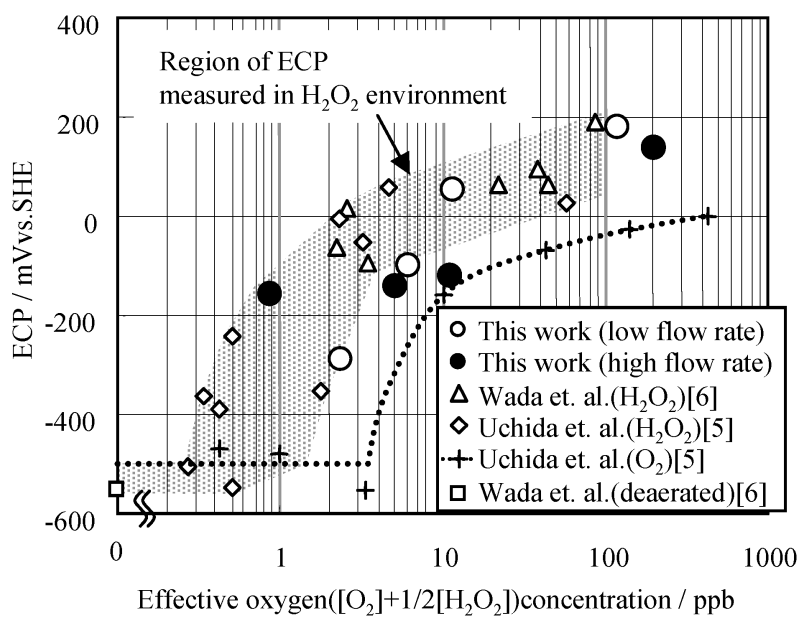

Fig. 5 ECPs obtained at high and low flow rates in various effective oxygen concentrations

\section{CGR 測定結果}

始めに, SEM による試験片の破面観察結果を Fig. 6 (a)，(b)に示す。疲労予き裂，強制破断面抢よび IGSCC の 領域は写真下のスケッチに示した。低流速, 高流速とも に, 疲労予き裂と強制破断面の中間に粗い粒子状の箇所が あり，これは Fig. 7 に示す拡大写真のように，ロックキ ヤンディ状の典型的な IGSCC の特徵を有したことから, IGSCC 領域と同定した。IGSCC は, 低流速, 高流速とも に試験片側面に近い個所で深く進展し, 板厚中央での進展 が比較的少なかった。

Figure 8(a),(b)に，RDC-PDM によるき裂長さ測定值 を，破面観察結果に基づいて実際のき裂長さに補正したき 裂長さ評価結果を示す。き裂長さの経時変化が水質の切り 替えに追従したことから，水質と流速の影響を調べる上で は, 少なくともこれらの試験片で得た CGR 值の相対比較 は有効であると考える。

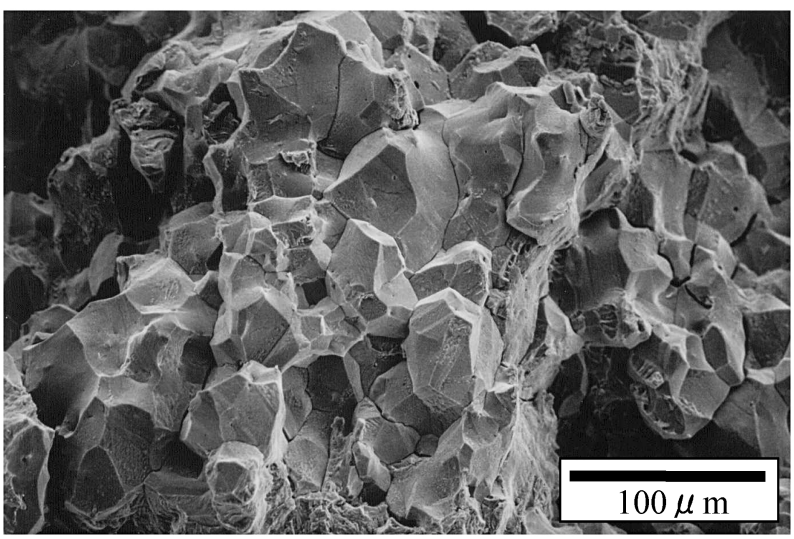

Fig. 7 Magnified image of IGSCC part of specimen

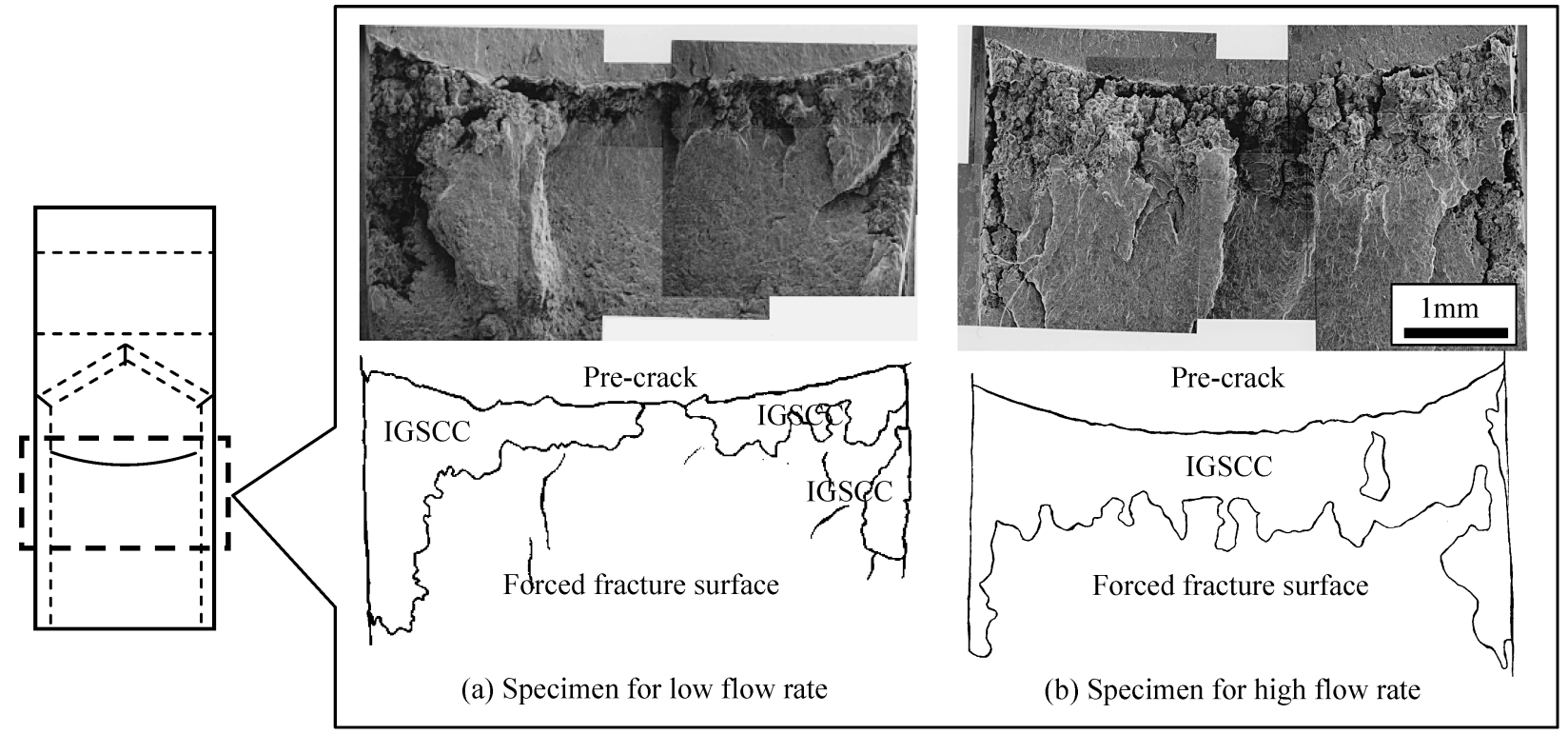

Fig. 6 SEM images of fracture surface of specimen after experiment 


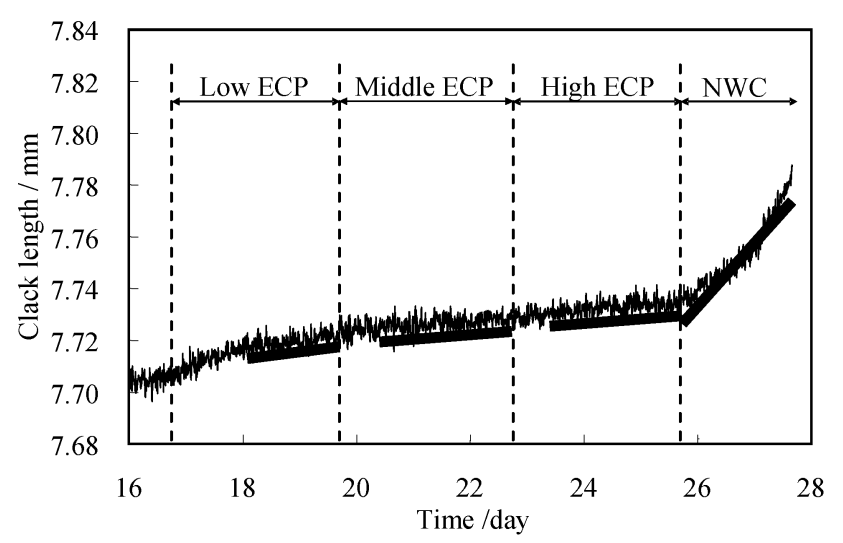

(a) Low flow rate test

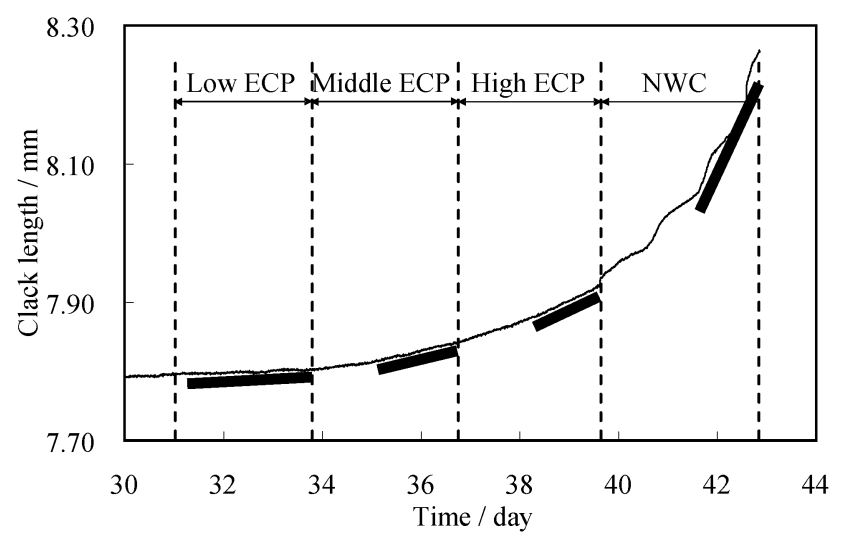

(b) High flow rate test

Fig. 8 Crack length vs. time

Figure 9 には, 本研究で得られた CGR を, NWC 条件 のCGRを 1 として算出した相対 CGR で表し, 低流速, 高流速ともに実効酸素濃度で整理した結果を示す。Figure 9 には，本研究と同様に $a / W=0.5$ の予き裂を導入した $1 /$ $4 \mathrm{TCT}$ 試験片で, 応力拡大係数 $27.5 \mathrm{MPa} \cdot \mathrm{m}^{0.5}$ で測定し た $\mathrm{CGR}^{6}$ )を相対 CGR に換算した結果をあわせて示す。

低流速では, 実効酸素濃度 $20 \mathrm{ppb}$ 以下の水素注入条件 としたとき，相対 CGR はいずれの水質でも約 0.1 まで低 下した。また，水素注入条件では，水質変化に対する CGR の変化はわずかであった。低実効酸素濃度となる水 素注入条件ではいずれも CGR が低いことから，水素注入 が CGR 抑制に有効であることを確認した。

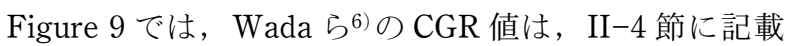
した周期的除荷を行わず，かつ水素を添加せずに測定され た結果であるが，Wada らの過酸化水素環境での CGR と 本研究の低流速でのCGR は比較的よく一致した。周期的 除荷を行うことで CGR は 2 倍程度に増大寸ると考えられ るが，本研究条件での周期的除荷に抢いては，CGRに及 ぼす影響は小さかったと考える。しかし，本研究の低 ECP 条件で CGR の低下が下げ止まる傾向を示したのは, 周期的除荷の影響が含まれている可能性も考えられる。 次に，流速の影響について述べる。高流速での相対

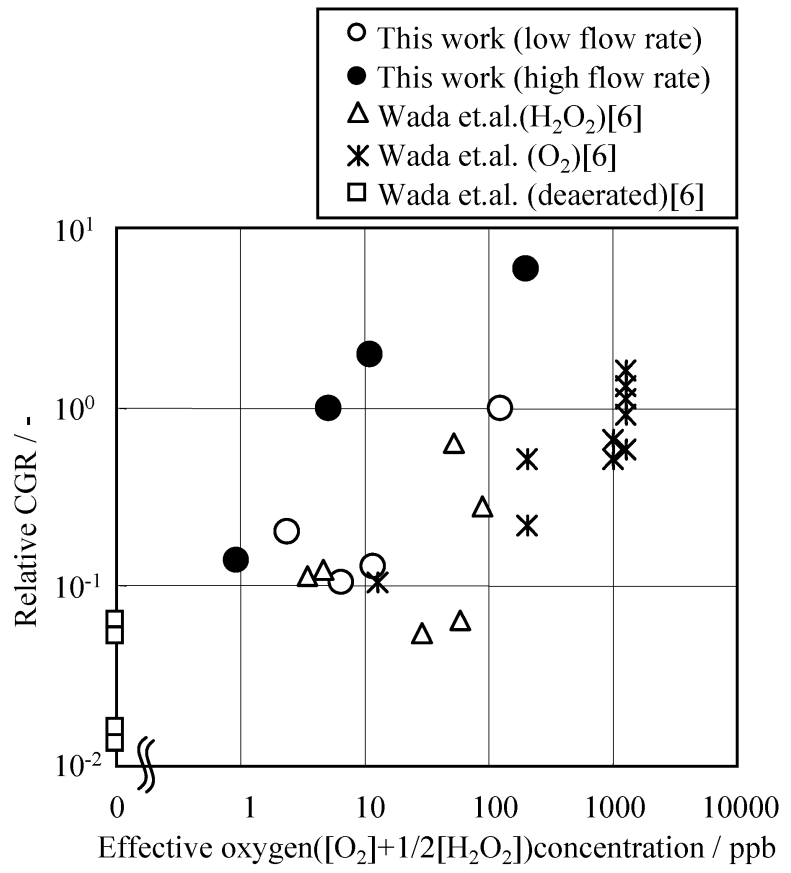

Fig. 9 Relationship between crack growth rate of type 304 stainless steel and concentrations of effective oxygen

CGR は，通常水質条件では6.0となり，低流速よりも一桁 近く高い值を示した。水素注入条件に切り替えると，実効 酸素濃度 (主として過酸化水素濃度)の低下とともにCGR は低下した。実効酸素濃度 $1 \mathrm{ppb}$ 程度まで低下すると， CGR は二桁程度小さくなり，低流速水素注入条件での相 対 CGR と同程度の0.14末で低下した。このことから, 高 流速環境でも水素注入によって実効酸素濃度が低下すれば, CGR が低減することを確認した。水素注入によって炉水 の酸化種濃度を十分に低下すれば，流速が高くても CGR は低下すると考える。

Figure 10 に, 相対 CGR の ECP 依存性を文献値6) とと もに示す。文献の ECP はいずれもバルク水中に設置した 板状 SUS304電極の ECP であるが，ノッチ内で測定され た ECP とバルク水中で測定された $\mathrm{ECP}$ とに差異がなか ったことから ${ }^{6)}$, 本研究のデータは CT 試験片のノッチ内 $\mathrm{ECP}$ でプロットした。なお, 文献6) ${ }^{6}$ C GR は, 本研究の 低流速条件と同様に準静止条件で取得されたものである。

低流速条件では, 約 $200 \mathrm{mV}$ vs. SHE で1.0の相対 CGR が，50〜200 mV vs. SHE の領域で大きく低下した。水素 注入条件の相対 CGR は，いずれも $0.11 〜 0.21$ まで低下し， $\mathrm{ECP}$ 変化による CGR 変化量が小さかった。

一方, 高流速での相対 CGR は, ECP が $200 \mathrm{mV}$ vs. SHE となる NWC 条件では6.0の高い値を指示した。水素 注入条件時の ECP はいずれも $-150 \sim-200 \mathrm{mV}$ vs. SHE 程度であって, 水質変化に対する $\mathrm{ECP}$ 変化量は小さかっ た。これは, 流速上昇により $\mathrm{ECP}$ が高く保持された結果 と考える。それにも関わらず，このわずかな $\mathrm{ECP}$ 範囲で 


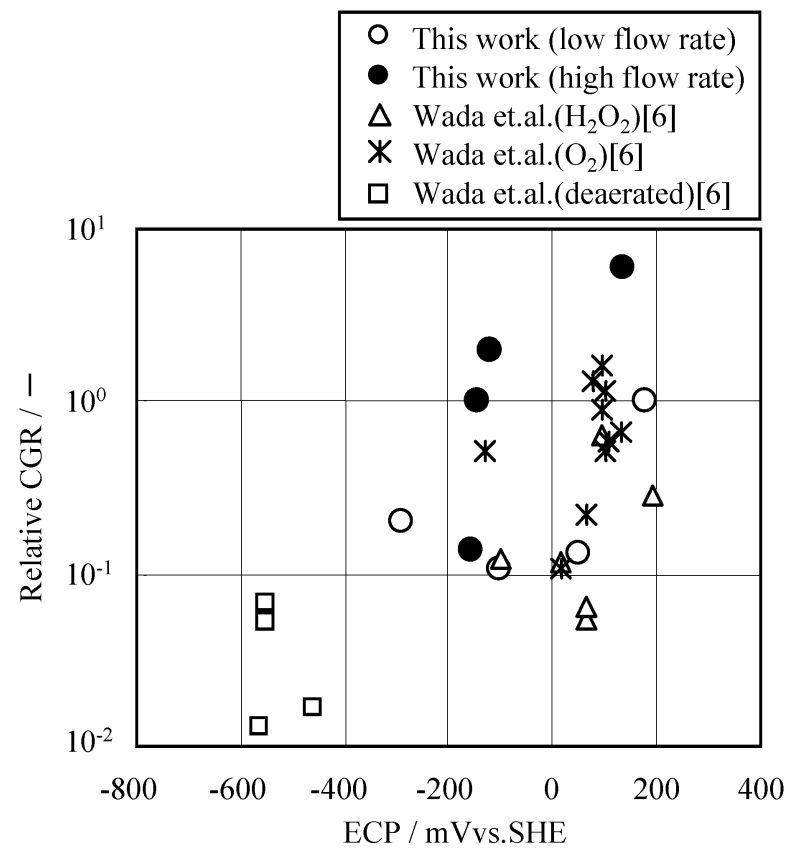

Fig. 10 Relationship between relative crack growth rate and electrochemical corrosion potential of type 304 stainless steel

水素注入水質の CGR は 1 桁の幅をもって变化した。高流 速では, 水素注入により酸化剂濃度が低下しても，低濃度 過酸化水素の存在により ECP が低下し難いが, 相対 CGR は0.11〜0.21まで低下することがわかった。このとき， CGR の ECP 依存性は小さく, むしろ酸化剤濃度の低下の 方が CGR の変化を表すのに適しているようにみえる。ま た，本実験では，フラッシングのような流速上昇による CGR 抑制効果は確認できなかった。

以上のことから，流速が異なる場合は，実効酸素濃度で 整理した場合でも，ECP で整理した場合でも，統一的に CGR を整理することは難しい。そこで，流速と酸化種濃 度双方で規定される，表面への酸化種供給速度で CGR を 整理することを試みる。

\section{IV. 考察}

\section{ECP に及ばす流れの影響}

流速が ECP に及ぼす影響については，これまでに多数 の実験的検討がなされている。一般に高流速では，カソー ド電流が増加して ECP が高くなる11 14)。これらの知見 は，流速上昇により拡散層厚が小さくなり，表面への酸化 剤の供給速度が増加することに起因していると考えられて いる。

本研究の結果 (Fig. 5) もまた, 流れによって拡散層厚が 減少し，低実効酸素濃度側では過酸化水素の供給量が増大 したことで ECP が高められたと考える。また，ECP は流 れの有無に関わらず実効酸素濃度の低下に伴って低下し た。したがって, 本研究の過酸化水素濃度条件では, 高流

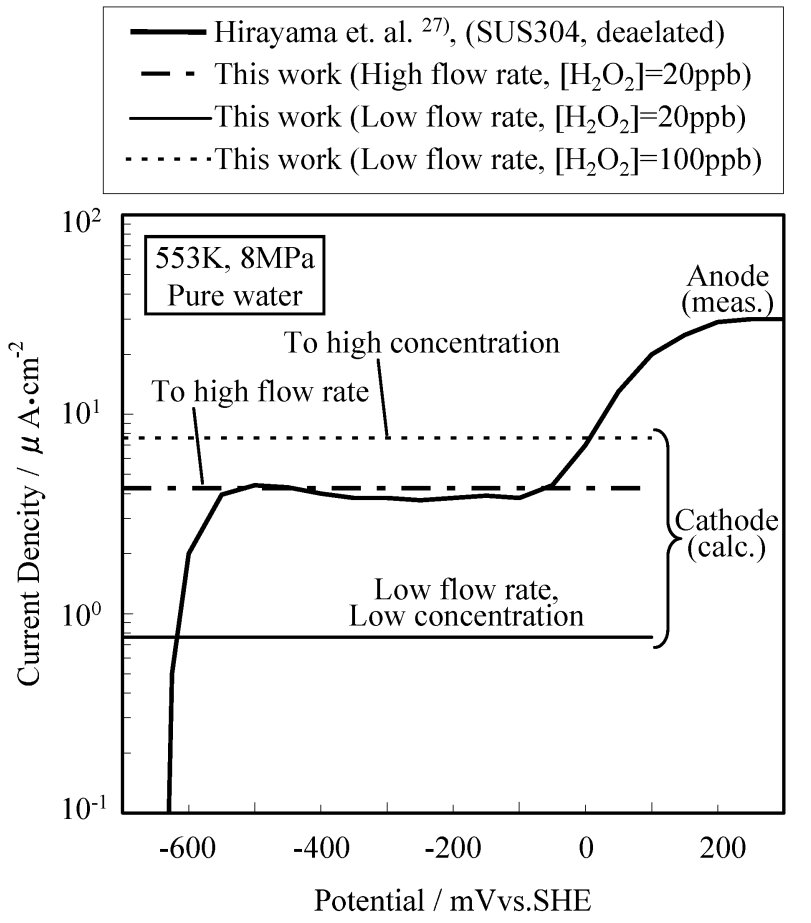

Fig. 11 Difference of flow rate dependence of ECP between high concentration and high flow rate

速条件でも拡散律速の影響を強く受けていると推定される。 そこで，本研究の流動条件におけるカソードの拡散限界 電流密度を計算し，平山ら 27 が実測したアノード分極曲 線とあわせて Fig. 11 に示した。流動加速腐食など, ア ノード面が流れに接する腐食形態では，溶液の流速変化に よりアノード電流密度も変化すると考えられるが, IGSCCではき裂先端がアノード面であり ${ }^{6}$, 直接流机に 接しないため，（4)式の溶出挙動に及ぼす流速の影響は 明らかではない。そのため,ここでは流れの影響を受けな いものと仮定し, 簡単のため, アノード反応は (4) 式に 示す金属の溶解反応のみ, カソード反応は (5) 式に示す 過酸化水素の還元反応のみを考え，(6)式によりカソー ドの拡散限界電流密度を求めた。Figure 11 には低流速の $\left[\mathrm{H}_{2} \mathrm{O}_{2}\right]=20,200 \mathrm{ppb}$, 高流速の $\left[\mathrm{H}_{2} \mathrm{O}_{2}\right]=20 \mathrm{ppb}$ の, 計 3 点の久を図示した。

$$
\begin{aligned}
& \mathrm{M} \longrightarrow \mathrm{M}^{2+}+2 \mathrm{e}^{-} \\
& \mathrm{H}_{2} \mathrm{O}_{2}+2 \mathrm{H}^{+}+2 \mathrm{e}^{-} \longrightarrow 2 \mathrm{H}_{2} \mathrm{O}+\mathrm{O}_{2} \\
& i_{\mathrm{L}}^{\mathrm{H}_{2} \mathrm{O}_{2}}=z F D_{\mathrm{H}_{2} \mathrm{O}_{2}} C^{\infty} \delta^{-1}
\end{aligned}
$$

ここで, $i_{\mathrm{L}}^{\mathrm{H}_{2} \mathrm{O}_{2}}$ は過酸化水素のカソード反応の拡散限界電 流密度 $\left(\mathrm{A} \cdot \mathrm{m}^{-2}\right), z$ は電荷数 $\left(\mathrm{eq} \cdot \mathrm{mol}^{-1}\right), F$ はファラデ 々定数 $\left(\mathrm{C} \cdot \mathrm{eq}^{-1}\right), \mathrm{C}^{\infty}$ はバルクの過酸化水素濃度 $(\mathrm{mol}$. $\left.\mathrm{m}^{-3}\right), \delta$ は拡散層厚さ $(\mathrm{m}), D_{\mathrm{H}_{2} \mathrm{O}_{2}}$ は過酸化水素の拡散係 数 $\left(\mathrm{m}^{2} \cdot \mathrm{s}^{-1}\right)$ である。低流速時の $\delta$ は, 停滞水に近い々仮 定して $0.05 \mathrm{~cm}$ を用いた。 $D_{\mathrm{H}_{2} \mathrm{O}_{2}}$ は, 高温水中に打ける過 酸化水素の拡散係数は熱的に不安定であり確立していない ため, Macdonald ら ${ }^{28)}$ に倣い酸素の拡散係数 $D_{\mathrm{O}_{2}}$ を代用 
した。 $D_{\mathrm{O}_{2}}$ と動粘性係数の温度依存性は,

$$
\begin{aligned}
& D_{\mathrm{O}_{2}}=8.31 \times 10^{-3} \exp \left(-3,490(R T)^{-1}\right) \\
& \ln (v)=-6.140834-1,103.164 T^{-1}+457,155.3 T^{-2}
\end{aligned}
$$

で求めた28)。

Figure 11 より，流速の上昇がバルクの過酸化水素濃度 増大時々同様に ECP を上昇させ，低流速で高濃度の場合 と，高流速で低濃度の場合とで同程度の ECP を指示する ことがあり得る。したがって高流速では，酸化種濃度が低 くても高 ECP を指示する。このため Fig. 5 では，低濃度 側で ECP が下げ止まる傾向を示したと考える。

一方 Fig. 5 に示した結果では，実効酸素濃度 $10 \mathrm{ppb}$ 以上 の領域に拈いて，高流速の ECP が低流速の ECP を下回 った。これは，流速上昇により拡散層厚が小さくなり，表 面への酸化剂の供給速度が増加するため ECP が上昇する 既往の知見と矛盾する。これは, 拡散層厚の減少により, 水素の供給量が増えたことに起因する可能性がある。

水素は，（4)式に示す金属の溶出反応に加えて，（9） 式の水素の酸化反応が重畳し，アノード電流が増加する。

$$
\mathrm{H}_{2} \longrightarrow 2 \mathrm{H}^{+}+2 \mathrm{e}^{-}
$$

したがって，Fig. 11のアノード分極曲線の電流密度が上 昇し，その結果 ECP は低下方向へ推移する。しかしなが ら，低流速の放射線非照射下では，酸素と水素を共存させ たのみでは，ステンレス鋼の ECP は低下し難く， $\mathrm{H}_{2} / \mathrm{O}_{2}$ モル比を 12 まで上昇させても ECP は $-0.1 \mathrm{~V}$ vs. SHE を 下回らないことがわかっている29)。一方，水質解析コ一 ドによる解析結果では, 流速上昇により水素の (9) 式に よるアノード電流が増大し，ECP が下がることが報告さ れている30)。したがって，低流速では水素の効果は顕著 ではないのに対し，流速の高い系では（9)式によるア ノード電流の増大による影響が強く現れ，その結果 ECP が低下した可能性がある。

\section{CGR に及ぼす流れの影響}

本研究の高流速 NWC 条件での CGR 実測の結果 (Fig. 10)は，低流速よりも 6 倍高い值を指示したが，そのとき の ECP は低流速と高流速とでほぼ同じであった。また， 高流速の水素注入条件では, ECPの変化量は少なかった が，酸化種濃度の減少に伴いCGR は急激に低下した。し たがって，本実験の流速の範囲では，ECPによって一義 的に CGR が決定せず，バルクから材料表面への酸化種の 供給速度が主体となって全体の腐食反応速度を決定したも のと考える。このことから，水素注入時の CGR 低減効果 は，酸化種濃度と供給速度，および $\mathrm{ECP}$ に基づいて評価 することが必要と考える。そこで, 表面への酸化種供給速 度が CGR を加速することを検討するために，得られた相 対 CGR を, 過酸化水素の物質移動量で整理することを試 みた。

物質移動量 $k$ を，(10) 式の乱流物質移動係数 $\kappa$ を用い
て, $k=\kappa \times\left(\right.$ 過酸化水素濃度 $\left./ \mathrm{mol} \cdot \mathrm{cm}^{-3}\right)$ で表すことで, 流動の影響を検討した。乱流条件での物質移動係数 $\kappa\left(\mathrm{cm} \cdot \mathrm{s}^{-1}\right)$ は (10) 式で求めた $\left.{ }^{31} 33\right)$ 。低流速条件では停滞 水とみなして $(11)$ 式で求めた。

$$
\begin{aligned}
& \kappa=0.026 S c^{0.33} R e^{0.8} D_{\mathrm{H}_{2} \mathrm{O}_{2}} \cdot d^{-1} \\
& \kappa=d \cdot \boldsymbol{\delta}^{-1}
\end{aligned}
$$

ここで $\operatorname{Re}\left(=d U \cdot v^{-1}\right)$ はレイノルズ数, $S c\left(=v \cdot D^{-1}\right)$ はシ ュミット数, $U$ は流速, $v$ は動粘性係数, $d$ は等価直径, $D_{\mathrm{H}_{2} \mathrm{O}_{2}}$ は過酸化水素の拡散係数, $\delta$ は拡散層厚さを表す。 等価直径 $d$ は, $d=4 S \cdot l^{-1}$ で求めた。 $S$ は流路断面積, $l$ は流路の外周長さである。 $D_{\mathrm{H}_{2} \mathrm{O}_{2}}$ は前述の理由で酸素の拡 散係数を用いた。材料表面で反応が生じる場合, 表面近傍 には拡散層が形成されており，酸化種の供給は一次元拡散 で支配されている。流動がない場合には，水の対流などで 生じた弱い流れが拡散層を形成するが，流動がある場合に は，層流あるいは乱流拡散層となる。 $R e$ (レイノルズ数) が4,000から5,000程度以上で乱流となる。高流速セル使用 時のReは約 3,000 となる。これは層流と乱流の遷移域で あるが, 本研究の流路形状が単純な直管ではなく層流は発 達し難いと考え，ここでは乱流であるものとみなして (10) 式を適用した。Table 1 にあわせて示したように， (10) 式から求めた本研究の高流速条件の $\kappa$ は $0.042 \mathrm{~cm} \cdot$ $\mathrm{s}^{-1}$ と得られ，これはBWRに拈けるダウンカマ部の $\kappa$ $\left(=0.063 \mathrm{~cm} \cdot \mathrm{s}^{-1}\right)$ とほぼ等価とみなせる。

相対 CGR を過酸化水素の物質移動量で整理した結果を Fig. 12 に示す。物質移動量で整理した場合，低流速と高 流速とがほぼ同じ傾向を示した。これは，CGR が酸化剂 のカソード反応量に依存することを示している。したがっ て，Fig. 10 に抢いて同レベルの ECPでも流速の違いに より CGR が異なったのは，流速増加により表面への過酸 化水素の供給量が増加し, 反応量が増加したことに起因す

Low flow rate OHigh flow rate - Regression formula

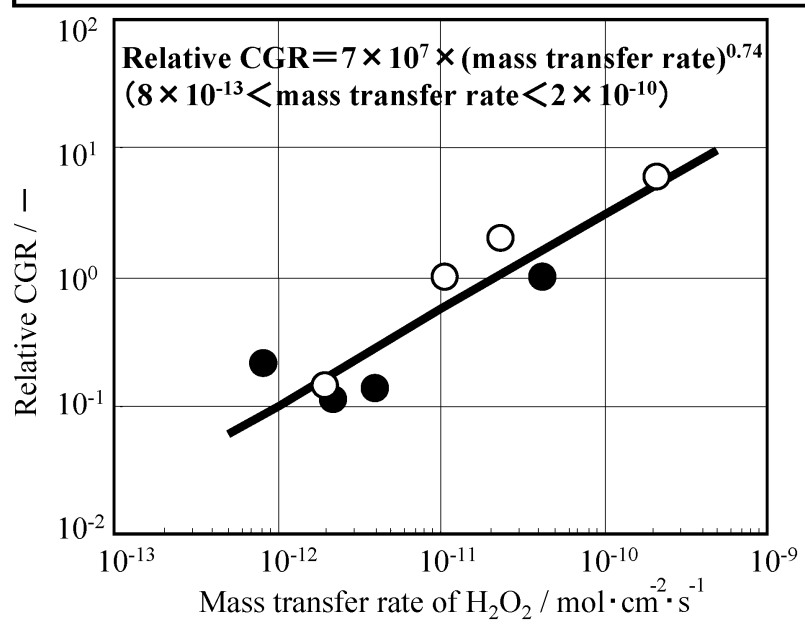

Fig. 12 Relationship between relative crack growth rate and mass transfer rate of $\mathrm{H}_{2} \mathrm{O}_{2}$ 
ると考える。

SCC の進展機構はまだ不明な点もあるが，き裂開口部 付近で生じる酸素, 過酸化水素のカソード反応と, き裂先 端の金属溶解のアノード反応が結合して進展すると考えら れている6)。き裂外表面は, き裂先端に比べて高 ECP で あるため，この電位差により局部電池が形成し，アニオン が濃縮することが知られている34)。したがってき裂外表 面 $\mathrm{ECP}$ の上昇は，き裂内環境を悪化させる原因になると 考えられる。一方, 物質移動量は, 局部電池内の電流に直 結する指標であるから ${ }^{6)}$, 物質移動量は，き裂先端での金 属溶解量と関係していると考える。そのため, 水素注入適 用による ECP 低下がわずかであっても，低濃度過酸化水 素によって ECP が高められている場合は, 物質移動量が 十分低下していれば CGR は抑制されると考える。

また, 本研究では, NWC 条件で高流速 CGR の方が低 流速 CGR よりも大きく，高流速条件でフラッシングによ る CGR 低減効果15) はみられなかった。これは，本研究で は高流速条件でも流速 $20 \mathrm{~cm} \cdot \mathrm{s}^{-1}$ であり，流れ方向がき 裂と平行であるのに対し，文献15)では，流速 $1.5 \mathrm{~m} \cdot \mathrm{s}^{-1}$ でき裂に垂直方向に流れを形成させているため，フラッシ ング効果に差異が生じたとも考えられる。Andresen ${ }^{35)}$ は，炭素鋼や低合金鋼などで直線的に割れる粒内割れで は，より早くフラッシングされるが，IGSCCなどの粒界 割れでは “経路屈曲”により，それほど顕著ではないとし ている。本研究では, CT 試験片のノッチ内に強制的に試 験水を流通させているため, CT 試験片の側面方向からも 試験水がき裂内に入ることで，より大きなフラッシング効 果が得られることが期待されたが，強制流通としたことで 酸化剤の供給量が著しく増加したことにより，CGR を上 昇させる作用が強く現れた可能性がある。そのため，今後 は James ら ${ }^{36)}$ が使用した，表面き裂型 CT 試験片を使用 した流れの研究が必要であると考える。

\section{V. 結 論}

流速が IGSCC に及ぼす影響を調べるため， $561 \mathrm{~K}$ の水 素注入模擬水質に扮いて，低流速 $\left(4 \mathrm{~mm} \cdot \mathrm{s}^{-1}\right)$, 高流速 $\left(20 \mathrm{~cm} \cdot \mathrm{s}^{-1}\right)$ の 2 ケースについてき裂進展試験を行い, CGR に対する過酸化水素環境中での流速の影響について 検討し，以下の結論を得た。

（1）低酸化種濃度域では，流速の上昇により ECP が上 昇した。このことから，流速の上昇は拡散層厚を小さく し，拡散により材料表面へ到達する酸化種の量を増加させ ていると考える。

（2）CGR を低下させるのは，材料表面への酸化種供給 量の低下が主であり，水素が直接 CGR を抑制する作用は 明らかではなかった。

（3）低流速において，NWCのCGRを1とした相対 CGR は，水素注入条件ではいずれの水質でも $0.1 \sim 0.2$ の 值を示し, NWC 条件より約 1 桁緩和された。
(4) 高流速の相対 CGR は, 実効酸素濃度 $10 \mathrm{ppb}$ 程度 以上では低流速条件よりも約 1 桁高い值を指示したが, 実効酸素濃度 $1 \mathrm{ppb}$ 程度となる水素注入条件では 0.14 とな り，これは低流速条件と同等の值であった。約 $-0.1 \mathrm{~V}$ vs. SHE 以下で ECP の下降とともに急激に小さくなり, $-0.16 \mathrm{~V}$ vs. SHE では低流速水素注入とほぼ同じ CGR ま で低下した。

（5）物質移動量の計算から，流速の上昇は，酸化種の供 給量を増加させることで CGR を増加する方向に影響する と考えた。CT 試験片のノッチ内に通水する場合, フラッ シング等による CGR 低減効果はみられなかった。

（6）高流速の環境である実機 BWR 炉内では，水素注入 の適用により過酸化水素の物質移動量を十分に低下させる と, CGR も低減すると評価した。

本研究は, 日本原子力発電秼, 東北電力秼, 東京電力 侏, 中部電力侏, 北陸電力侏, 中国電力秼, 財電力中央研 究所, 侏東芝, 侏日立製作所が実施した共同研究「材料健 全性に及ぼす過酸化水素の影響評価研究」の成果の一部で ある。

\section{[記号·略号]}

SUS304：JIS G4303(1991)で規定されるオーステナイトステ ンレス鋼の規格

IGSCC : Intergranular Stress Corrosion Cracking, 応力腐食 割れ

HWC : Hydrogen Water Chemistry, 水素水化学, 水素注 入

BWR : Boiling Water Reactor, 沸騰水型原子炬

CT : Compact Tension, 二重片持梁型試験片の一形態

ECP : Electrochemical Corrosion Potential, 電気化学腐食 電位

V vs. SHE : Volt versus Standard Hydrogen Electrode, 標準水 素電極電位を基準として表示した電極電位

CGR : Crack Growth Rate，き裂進展速度

PDM : Potential Drop Method, 電位差法

JSME : The Japan Society of Mechanical Engineers, 日本 機械学会

DCB : Double Cantilever Beam, 2 重片持梁型(試験片)

SIMFONY : SIMulation For Optimum Net Yield in chemical engineering plants, 水質解析コード

PTFE : Polytetrafluoroethylene : PTFE, 四フッ化エチレン 樹脂

$K$ 值 : 応力拡大係数

RDC-PDM : Reversing Direct Current-PDM, 交番直流電位差法

SEM : Scanning Electron Microscope, 走查型電子顕微鏡

NWC : Normal Water Chemistry, 通常水質

$\eta_{\mathrm{CT}} \quad: \mathrm{CT}$ 試験片位置での過酸化水素残存率

$C_{\mathrm{CT}} \quad: \mathrm{CT}$ 試験片位置での過酸化水素濃度

$C_{\mathrm{inj}} \quad:$ 系統水への過酸化水素混合点での過酸化水素濃度

$R_{\mathrm{p}} \quad$ : 塑性域寸法

$\left[\mathrm{O}_{2}\right]_{\mathrm{eff}} \quad:$ 実効酸素濃度 $\left(=\left[\mathrm{O}_{2}\right]+1 / 2\left[\mathrm{H}_{2} \mathrm{O}_{2}\right]\right)$

$k \quad$ : 物質移動量

$\kappa \quad$ : 乱流物質移動係数 
1) R. L. Cowan, "The mitigation of IGSCC of BWR internals with hydrogen water chemistry," Proc. Int. Conf. Water Chemistry of Nuclear Reactor Systems, Water Chemistry 7, Brit. Nucl. Energy Soc., 196 (1996).

2) R. L. Cowan, M. E. Indig, J. N. Kass et al., "Experience with hydrogen water chemistry in boiling water reactors," Water Chemistry in Nuclear Reactor System 4, BNES, London, 29 (1986).

3) P. L. Andresen, F. P. Ford, "Life prediction by mechanistic modeling and system monitoring of environmental cracking of Fe and Ni alloys in aqueous systems," Mater. Sci. Eng., A103, 167 (1988).

4）山脇道夫，恩地健雄，福谷耕司，他，“BWR 炉心シュラウド 等の応力腐食割れに係わる最近の研究動向, ” 日本原子力学 会誌，47[6], 385 (2005).

5) S. Uchida, N. Shigenaka, M. Tachibana et al., "Effects of hydrogen peroxide on intergranular stress corrosion cracking of stainless steel in high temperature water, (I); Effects of hydrogen peroxide on electrochemical corrosion potential of stainless steel,” J. Nucl. Sci. Technol., 35, 301 (1998).

6) Y. Wada, A. Watanabe, M. Tachibana et al., "Effects of hydrogen peroxide on intergranular stress corrosion cracking of stainless steel in high temperature water, (III); Crack growth rates in corrosive environment determined by hydrogen peroxide," J. Nucl. Sci. Technol., 37, 901 (2000).

7) S. Uchida, M. Tachibana, A. Watanabe, "Effects of hydrogen peroxide on intergranular stress corrosion cracking of stainless steel in high temperature water, (II); Optimization of crack propagation rate measurement system," J. Nucl. Sci. Technol., 37, 257 (2000).

8) Y. Murayama, T. Satoh, S. Uchida et al., "Effects of hydrogen peroxide on intergranular stress corrosion cracking of stainless steel in high temperature water, $(\mathrm{V})$; Characterization of oxide film on stainless steel by multilateral surface analyses," J. Nucl. Sci. Technol., 39, 1199 (2002).

9) J. Sugama, S. Uchida, N. Yamashiro et al., "Effects of hydrogen peroxide on corrosion of stainless steel, (II); Evaluation of oxide film properties by complex impedance measurement," J. Nucl. Sci. Technol., 41, 880 (2004).

10) T. K. Yeh, "An improved model for assessing the effectiveness of NMCA in boiling water reactors," Proc. 10th Int. Symp. Environmental Degradation of Materials in Nuclear Power Systems-Water Reactors, Lake Tahoe, Nevada, Aug, 5-9,
2001, NACE, No. 87 (2001).

11) M. Sambongi, S. Suzuki, N. Ichikawa et al., "The effect of $\mathrm{H}_{2} \mathrm{O}_{2}$ on ECP under a variety of flow rate and temperature," Proc. 9th Int. Symp. Environmental Degradation of Materials in Nuclear Power Systems-Water Reactors, Newport Beach, California, August 8-12, 1999, TMS (1999).

12) C. C. Lin, F. R. Smith, N. Ichikawa et al., "Electrochemical potential measurements under simulated BWR water chemistry conditions," Corrosion, 48, 16 (1992).

13) Y. J. Kim, C. C. Lin, R. Pathania, "Effect of water flow velocity on electrochemical corrosion potential of stainless steel in $288^{\circ} \mathrm{C}$ water," Corrosion, 49, 10 (1993).

14) R. Katsura, S. Nishimura, "Evaluation of the flow rate effect on the corrosion potential of stainless steel in high temperature water using a rotating electrode systems," Proc. Plant Aging and Life Prediction of Corrodible Materials, Sapporo, 1995, JSCA, 749 (1995).

15) P. L. Andresen, "Effects of flow rate on SCC growth rate behavior in BWR water," Proc. 8th Int. Symp. Environmental Degradation of Materials in Nuclear Power Systems-Water Reactors, Amelia Island, California, Aug. 13-15, 1997, NACE, 603 (1997).

16) G. A. Fuller, D. D. Macdonald, "The effect of fluid flow on the stress corrosion cracking of AISI 304 stainless steel in $0.01 \mathrm{M}$ $\mathrm{Na}_{2} \mathrm{SO}_{4}$ solution at $280^{\circ} \mathrm{C}$," Corrosion, 40, 474 (1984).

17) H. Choi, F. H. Beck, Z. Szklarska-Smialowska et al., "The effect of fluid flow on the stress corrosion cracking of ASTM A508 Cl 2 steel and AISI type 304 stainless steel in high temperature water," Corrosion, 38, 76 (1982).

18) S. H. Shim, Z. Szklarska-Smialowska, "Effect of fluid flow on the stress corrosion cracking of AISI 304 stainless steel in pure water and $0.01 \mathrm{~N} \mathrm{Na}_{2} \mathrm{SO}_{4}$ solutions differing in $\mathrm{pH}$," Corrosion, 43, 286 (1987).

19) H. S. Kwon, A. Wuensche, D. D. Macdonald, "Effects of flow rate on crack growth in sensitized type 304 stainless steel in high-temperature aqueous solutions," Corrosion, 56, 482 (2000).

20）菊池英二，大中紀之，湊 昭，他，“繰り返し SSRT 法による 鋭敏化 SUS304ステンレス鋼のIGSCC に及ぼす環境因子の 影響評価,”防食技術，32, 497 (1983).

21) E. Ibe, S. Uchida, "Radiolytic aspects in boiling water reactor primary systems: Results from numerical simulations and statistical regression analyses," Nucl. Sci. Eng., 89, 330 (1985).

22) T. Sato, T. Shoji, "Effects of specimen size and thickness on CGR in high temperature waters," Proc. 11th Int. Symp. Environmental Degradation of Materials in Nuclear Power Systems-Water Reactors, Stevenson, Washington, Aug. 10-14, 2003, NACE, 862 (2003).

23) P. L. Andresen, " $K /$ size effects on SCC irradiated, cold worked and unirradiated stainless steel," Proc. 11th Int. Symp. Environmental Degradation of Materials in Nuclear Power Systems-Water Reactors, Stevenson, Washington, Aug, 10-14, 2003, NACE, 870 (2003).

24) A. Molander, B. Bengtsson, C. Jansson et al., "Influence of flow-rate on the critical potential for IGSCC of stainless steel in simulated BWR environment," Proc. 8th Int. Symp. Environmental Degradation of Materials in Nuclear Power Systems-Water Reactors, Amelia Island, California, Aug. 13-15, 
1997, NACE, 615 (1997).

25) D. Weinstein, "Real time, in-reactor monitoring of double cantilever beam crack growth sensors," Proc. 6th Int. Symp. Environmental Degradation of Materials in Nuclear Power Systems-Water Reactors, San Diego, California, Aug. 1-5, 1993, NACE, 645 (1993).

26) P. L. Andresen, "Effects of specific anionic impurities on environmental cracking of austenitic materials in $288^{\circ} \mathrm{C}$ water," Proc. 5th Int. Symp. Environmental Degradation of Materials in Nuclear Power Systems-Water Reactors, Monterey, California, Aug. 25-29, 1991, NACE, 209 (1991).

27）平山秀雄, 山科泰之, 中村新一, 他, “高温純水中の電位制 御下に打ける304鋼の SCC 感受性と皮膜性状, ”Boshoku Gijutsu, 34, 86 (1985).

28) D. D. Macdonald, "Viability of hydrogen water chemistry for protecting in-vessel components of boiling water reactors," Corrosion, 48, 194 (1992).

29) S. Hettiarachchi, G. P. Wozadlo, P. L. Andresen et al., "The concept of noble metal chemical addition technology for IGSCC mitigation of structural materials," Proc. 7th Int. Symp. Environmental Degradation of Materials in Nuclear Power Systems-Water Reactors, Breckenridge, Colorado, August 710, 1995, NACE, 735 (1995).

30) Y. Wada, K. Ishida, M. Tachibana, "Effectiveness analysis of noble metal treatment to mitigation of intergranular stress corrosion cracking of stainless steel in BWR reactor water environment," Proc. 11th Int. Symp. Environmental Degradation of Materials in Nuclear Power Systems-Water Reactors, Stevenson, Washington, Aug. 10-14, 2003, NACE, 488 (2003).

31) E. L. Cussler, DIFFUSION Mass Transfer in Fluid Systems, Cambridge University Press (1991).

32) C. C. Lin, "Decomposition of hydrogen peroxide in aqueous solutions at elevated temperatures,"' Int. J. Chem. Kinet., 23, 971 (1991).

33) R. A. Holser, G. Prentice, R. B. Pond Jr. et al., "Use of rotating cylinder electrodes to simulate turbulent flow conditions in corroding systems," Corrosion, 46, 764 (1992).

34) Q. Peng, G. Li, T. Shoji, "The crack tip solution chemistry in sensitized stainless steel in simulated boiling water reactor water studied using a microsampling technique," J. Nucl. Sci. Technol., 40[6], 397 (2003).

35) P. L. Andresen, "SCC testing and data quality considerations," Proc. 9th Int. Symp. Environmental Degradation of Materials in Nuclear Power Systems-Water Reactors, NewportBeach, California, August 8-12, 1999, TMS (1999).

36) L. A. James, H. B. Lee, G. L. Wire, "The effect of water flow rate upon the environmentally assisted cracking response of a low-alloy steel: Experimental results plus modeling,"' J. Press. Vess. Techol., 119, 83 (1997). 